\title{
The Implementation of Situational Accompaniment
}

\author{
Istiningsih* \\ Associate Professor, Faculty of Education, State Islamic University Sunan Kalijaga Yogyakarta \\ Pos Code 55288, Indonesia \\ Muh. Wasith Achadi \\ Faculty of Education, State Islamic University Sunan Kalijaga Yogyakarta, Pos Code 55288, Indonesia
}

\begin{abstract}
The research is financed by Margono's Foundation
\section{Abstract}

The terminology of accompaniment is very popular in the community, especially in the education sector. However, specific assistance is still rare. Likewise, the implementation of ideal accompaniment is rarely done. Thus the terminology of accompaniment is only like rhetoric without a tangible existence. This study combines accompaniment with situational leadership. The research method is a mix method with sequential exploratory techniques. The results of the research on 16 students were the types of delegating, participating, motivating and instructing. Delegating is implemented for the students who are strong for their learning motivation and academic capabilty. Participating is implemented for the students who are strong for their learning motivation but weak for academic capabilty. Motivating is implemented for the students who are weak for their learning motivation but strong for academic capabilty. Instructing is implemented for the students who are weak for their learning motivation and academic capabilty.
\end{abstract}

Keywords: Accompaniment, Situational Leadership

DOI: $10.7176 / \mathrm{JEP} / 11-27-15$

Publication date:September $30^{\text {th }} 2020$

\section{Introduction}

The term accompaniment has spread in various sectors in both government and non-governmental institutions. The term accompaniment is widely used in the sectors of education, health, economy, agriculture, fisheries and so on. The term accompaniment appeared sporadically about a decade ago. This is in accordance with the opinion (Ardian, 2011).

The term accompaniment has a deeper meaning than the term teaching. Teaching is as if it is only one way traffic of communication, while accompaniment two ways traffic of communication. In addition, the term teaching has a meaning as if the ability that the learner will achieve is designed by the teacher, while in the terms of accompaniment, the goal of learning achievement is designed by or desired by the learner (Yaumi, 2018).

The deeper meaning of the term accompaniment among them is that students are not the object of education. Students are subjects who will build themselves into empowered personnel with their abilities. The involvement of educators with the learner is very strong in designing the orientation of education that he does.

The term accompaniment that has been applied in various sectors since a few years ago until now, observed by researchers has no peculiarities. Istiningsih (2008) raised the term accompaniment with its peculiarities based on the uniqueness of the accompanying students, and named among the accompaniment. The term Among is derived from the opinion of Ki Hadjar Dewantara, which is derived from Javanese. the meanings of asah, compassion and foster care (Djohar and Istiningsih, 2017).

Istiningsih (2008) outlined the philosophy of Among is the uniqueness of students. The concepts of are (1) individual, (2) cases, and (3) case resolution.The mechanisms of Among are as follows (1) Ing Ngarso Sung Tulodho, (2) Ing Madyo Mangun Karso, and (3) Tut Wuri Handayani. The mechanism of Among stated above is analogous to the thinking of Hersey and Blanchard (1977) called situational leadership.

The leadership style approach is only focused on followers or subordinates in an organization. The implementation of such force is based on the maturity and readiness of employees and subordinates in carrying out tasks or burdens given to him (Harsey and Blanchard, 1997). Widiyanto (2013) has another view, that situational leadership measurement is carried out through the willingness and ability of employees to do their job.

This research aims to improve the situational accompaniment model according to Harsey and Blanchard (1997) as well Istiningsih (2008) above. This research will (1) describe the implementation of situational accompaniment on The Education Leadership course of Faculty of Education, State Islamic University 'Sunan Kalijaga' Yogyakarta, (2) predict the tendency of academic capaability and learning motivation of students after getting situational accompaniment, and (3) measure the effectiveness of situational accompaniment conducted by lecturers to their guidance students. This research was conducted in postgraduate programs, more specifically for education leadership courses on Islamic Education Teacher For master degree at Faculty of Education State Islamic University 'Sunan Kalijaga' Yogyakarta. 


\section{Theory}

\section{Accompaniment}

Payne (1986), mentoring was a strategy that prioritized "making the best of the client's resources". Directorate of Social Assistance (2007), Mentoring is a process of providing assistance to clients in identifying needs and solving problems and encouraging the growth of initiatives in the decision-making process, so that self-reliance can be realized.

According to the Family Planning association, East Java (2001:5) mentoring can also be an activity carried out and can mean coaching, teaching, directing in groups that are more connotated on mastering, controlling, and controlling. Istiningsih (2008) Mentoring is a process of facility to parties accompanied by self-orientation, creative and empowered.

\section{Definition of Situational leadership}

Situational leadership style is the pattern of behavior that a leader shows when leading at a time when influencing the activities of others as both individuals and groups (Aisha and Takdir, 2017). The level of emotional support (relationship behavior) that the leader provides. The level of readiness shown in carrying out specific tasks, functions or purposes (Thoha, 1996:64)

\section{Academic Capability}

The term academic capability consists of two words, namely ability and academic. In the Great Dictionary of Bahasa Indonesia, capaability has the meaning of capaability, proficiency, or strength, while academic means related to academic (education). According to Krishnawati and Suryani (2010) academic capaability is part of intellectual ability that is generally reflected in academic achievement (the value of learning outcomes). The concept of academic ability is an individual's beliefs and self-evaluation of the academic nature associated with the individual's skills and abilities (McGrew, 2008). Students' academic abilities can be drawn from their academic achievements. Academic achievement is an accumulative function of family, community, and school experience both past and present (Rivkin, et al., 2005). This is supported by Dahar (2011) statement which states that the achievement or academic achievement of previous students demonstrates the academic ability and performance of students in the previous class.

Education Leadership Course Materials in Islamic Teacher Education Program - Master degree Faculty of Education State Islamic University 'Sunan Kalijaga' Indonesia.
a.Definition of Educational Leadership
b.Differences in Educational Leadership with Non-Educational Leadership
c. Indicators of reliable education leaders
d.Strategy of building mental leadership
e. Education leadership case in Indonesia
f. Education leadership case resolution strategy in Indonesia
g.Design good education in schools, madrassas and contextual universities

\section{Motivation}

Motivation is an internal process that activates, guides, and maintains behavior over time. There are many different types, intensities, objectives, and motivational directions (Sulihin, 2012) Internal motivation can encourage students to learn naturally without being influenced by outside factors. Interest is one of the motivational factors identified in the study. A student with a learning interest will certainly be more motivated than those driven by parents, family or friends (Aiyub, 2015)

Komsiyah mentions Interest as part of the intrinsic motivation that is included as a psychological factor in influencing internal learning processes and results (Komsiyah, 2012) so that learning needs to be considered and adapted to one's interests (Nursalam and Efendi F, 2008), in addition, Susilo mentions that one's ideals are part of the intrinsic motivation that becomes the center of psychic energy to learn (Susilo R, 2011)

According to Winkel (2003) the definition of learning motivation is all efforts within themselves that give rise to learning activities, and ensure the continuity of learning activities and give direction to learning activities so that the desired goals are achieved. Learning motivation is a psychic factor that is non-intellectual and plays a role in fostering a spirit of learning for individuals.

According to Bophy (1987) The definition of learning motivation is as a general state and as a situationspecific state. As a general state, learning motivation is a permanent disposition that encourages a person to master knowledge and skills in a learning activity. While as a situation-specific state, learning motivation arises because an individual's involvement in a particular activity is directed by the purpose of acquiring knowledge or mastering the skills taught.

Learning motivation indicators as follows.

a.Diligently face the task. 
b. Tenacity faces difficulties.

c. Show interest in a wide range of issues.

d.Prefer to work independently.

e. Get bored of routine tasks quickly.

f. Can defend his opinion.

g.It is not easy to let go of what he believes.

h.It's good to find and solve questions.

In addition to the above indicators, Schwtzgebel and Kalb explained and quoted by (Djaali, 2009) that a person with high learning motivation can be seen from the following indicators:

a. Like situations or tasks that claim personal responsibility for the results and not on the basis of profit, fate, or coincidence.

b. Choose goals that are realistic, but challenging from goals that are too easily achieved or too big a risk.

c. Look for situations or jobs where he or she obtains immediate and tangible feedback to determine whether or not his work is done.

d. It's nice to work alone and compete to outperform others.

e. Able to suspend the fulfillment of his wishes for a better future. Unable to simply earn money, status, or other benefits, he will look for it if these things are emblematic of achievement or a measure of success.

\section{Research Methods}

Types of research

This research is a mix method, which integrates qualitative and qualitative approaches (Wisdom and Creswell, 2013). To answer question number 1 qualitatively and for questions 2 and 3 using quantitative, thus the technique used is sequential exploratory (Sugiono, 2013).

\section{Data collection}

Research is conducted during one semester (from the beginning of the lecture to the end of the lecture), for 14 weeks. This research was conducted to 16 students who after the initial test were on four characteristics namely students with characteristics (1) "high ability - high motivation", (2) students with characteristics of "high ability - low motivation", (3) students with characteristics of "low ability - high motivation", (4) students with characteristics of "low ability - low motivation

Table 1 The Table Below Showes Instrument For Collect Data Of Learning Motivation Of Students

\begin{tabular}{|c|l|r|r|r|r|}
\hline NO & \multicolumn{1}{|c|}{ STATEMENT } & \multicolumn{3}{|c|}{ SCORE } \\
\hline & \multicolumn{1}{|c|}{} & $\mathbf{2}$ & $\mathbf{3}$ & $\mathbf{4}$ \\
\hline 1 & Happy to search learning material and problem solving & & & & \\
\hline 2 & Tenacious to face adversity & & & & \\
\hline 3 & It's nice to work alone and compete to outperform others & & & & \\
\hline 4 & Show interest in various problems & & & & \\
\hline 5 & Prefer to work independently & & & & \\
\hline
\end{tabular}

Table 2 The Table Below Showes Instrument For Collect Data Of Academic Capability Of Students

\begin{tabular}{|c|l|c|c|c|c|}
\hline NO & \multicolumn{1}{|c|}{ STATEMENT } & \multicolumn{3}{|c|}{ SCORE } \\
\hline 1 & Definition of Educational Leadership & $\mathbf{1}$ & $\mathbf{2}$ & $\mathbf{3}$ & $\mathbf{4}$ \\
\hline 2 & Differences in Educational Leadership with Non-Educational Leadership & & & & \\
\hline 3 & Indicators of reliable education leaders & & & \\
\hline 4 & Mental leadership building strategy & & & \\
\hline 5 & Education leadership case in Indonesia & & & \\
\hline
\end{tabular}

\section{Data analysis}

Qualitative data is analyzed by pattern (Miles and Huberman, 1984). with data collection, data reduction, display data, and conclusion stages. While quantitative data is analyzed using trend analysis.

\section{Results and Discussions}

Based on the data obtained results: the condition of the student's academic capability about his understanding of the science of leadership of the education with the average score of each student which can be seen in table 3 below. For minimum scores are 1.95 and maximum scores are 3. 37. The average score of 16 students is 1.87

Based on the data obtained results: the motivational condition of students about the science of leadership education with the average score of each student can be seen in table 3 below. Minimum scores are 1.90 and 
maximum scores are 3. 27. for further answers to research question number 2, the situational accompaniment process is described in detail and discussed thoroughly in the section below.

The trend of changes in academic capability and motivation of student after being accompanied shows an increase althougt the in increasing is not signfican. The first point is $52.29 \%$ and the last point is $53.95 \%$ for academic capability. The first point is $53.75 \%$ and the last point is $53.75 \%$ for learning motivation.

The are on the some category. The detil result of analisys effectiveness of accompaniment by lecturers with this situational pattern of achieving. detail and in accordance with the purpose of the research is presented as follows.

\section{Mapping academic skills and student learning motivation}

The academic ability of the student as well as his learning motivation is presented in the table below. The two variables were observed and subsequently replaced with scores of $1-4$. Scores of 1 to 2.5 are categorized at low positions, while scores of 2.6 to 4 are categorized at high positions.

Observations were made six times. The first observation is carried out before the assistance is made, while the second to sixth observations are carried out in hand with the mentoring process. The time distance of each observation ranges from 10 to 15 days. Although time is not done analysis, it needs to be conveyed in this study to maintain data objectivity.

The preparation of the table below is as follows, for the order of students no. $1-4$ which includes the high criteria of academic ability as well as the high motivation of learning. Number $5-8$ which includes high criteria for academic ability but low learning motivation. For sequences number $9-12$ which includes low academic ability but high learning motivation. Number $13-16$ which includes his low academic ability as well as his learning motivation. These categories are grouped by average from each observation.

Table 3 Academic Capability and Motivation

\begin{tabular}{|r|r|r|r|r|r|r|r|r|r|r|r|r|r|r|}
\hline \multicolumn{1}{|c|}{ No } & \multicolumn{1}{|c|}{ Obademic Capability } & \multicolumn{7}{|c|}{ Obarning Motivation } \\
\hline & 1 & 2 & 3 & 4 & 5 & 6 & Mean & 1 & 2 & 3 & 4 & 5 & 6 & Mean \\
\hline 1 & 2.8 & 3.1 & 2.9 & 3.0 & 3.4 & 3,3 & 3.08 & 2.9 & 2.8 & 3.0 & 3.5 & 3.4 & 3.1 & 3.11 \\
\hline 2 & 3.5 & 3.2 & 3.2 & 3.3 & 3.6 & 3,4 & 3.37 & 3.5 & 3.4 & 3.2 & 2.8 & 3.6 & 3.1 & 3.27 \\
\hline 3 & 3.7 & 3.2 & 3.1 & 3.3 & 3,6 & 3.0 & 3.32 & 2.9 & 2.8 & 2.7 & 2.6 & 2.9 & 3.0 & 2.82 \\
\hline 4 & 3.2 & 2.9 & 3.1 & 2.9 & 2,9 & 3.1 & 3.02 & 3.2 & 2.9 & 3.0 & 3.4 & 3.2 & 3.6 & 3.21 \\
\hline 5 & 3.1 & 3.0 & 3.4 & 2.8 & 3,6 & 2.9 & 3.13 & 2.4 & 2.2 & 2.0 & 1.8 & 1.7 & 1.9 & 2.00 \\
\hline 6 & 2.9 & 3.2 & 3.0 & 3.6 & 2,8 & 3.7 & 3.20 & 1.8 & 1.4 & 2.3 & 2.4 & 1.5 & 2.3 & 1.95 \\
\hline 7 & 2.8 & 3.3 & 3.0 & 3.8 & 3,8 & 3.8 & 3.41 & 2.3 & 2.1 & 2.0 & 2.4 & 1.2 & 1.4 & 1.90 \\
\hline 8 & 2.7 & 2.9 & 2.8 & 2.7 & 3,5 & 3.1 & 2.95 & 1.4 & 1.9 & 2.0 & 2.4 & 2.2 & 2.0 & 1.98 \\
\hline 9 & 3.0 & 1.2 & 1,4 & 1.8 & 1,2 & 1.5 & 1.68 & 3.2 & 3.4 & 2.8 & 3.0 & 3.2 & 3.8 & 3.23 \\
\hline 10 & 2.0 & 2.1 & 2.9 & 1.1 & 1,6 & 1.5 & 1.86 & 3.0 & 3.3 & 2.6 & 2.7 & 3.3 & 3.3 & 3.03 \\
\hline 11 & 2.9 & 2.1 & 2.8 & 2.1 & 2,1 & 2.8 & 2.47 & 2.9 & 3.0 & 2.7 & 3.8 & 3.1 & 3.2 & 3.12 \\
\hline 12 & 1.3 & 2.3 & 1.4 & 2.2 & 2,3 & 2.1 & 1.93 & 2.8 & 2.9 & 2.9 & 3.3 & 2.9 & 2.8 & 2.93 \\
\hline 13 & 1.9 & 1.5 & 1.2 & 2.8 & 2.0 & 2.1 & 1.92 & 2.1 & 2.2 & 2.8 & 2.0 & 2.0 & 2.4 & 2.25 \\
\hline 14 & 2.1 & 2.0 & 1.9 & 2.3 & 2.1 & 2.0 & 2.07 & 3.0 & 2.0 & 1.2 & 1.9 & 1.9 & 1.9 & 1.98 \\
\hline 15 & 2.0 & 2.2 & 2.1 & 1.6 & 1.8 & 2.0 & 1.95 & 3.0 & 1.9 & 2.0 & 2.6 & 1.8 & 1,8 & 2.18 \\
\hline 16 & 1.2 & 2.5 & 2.0 & 2.1 & 1.8 & 1.6 & 1.87 & 1.4 & 2.9 & 1.4 & 2.9 & 2.3 & 2.3 & 2.20 \\
\hline
\end{tabular}

Score: 1.0-2.5 Low; 2.6-4.0 High

\section{Description of situational accompaniment process}

In accordance with the theory put forward by Harsey and Blanchard (1977) and used as a platform for data retrieval and analysis, the following data is obtained.

\section{Delegating pattern}

This delegating pattern is applied to students with characteristics of "high academic ability as well as high learning motivation". Delegating means that lecturers give problems to students and students to solve them only with consultation if necessary. Because students have high academic ability and high motivation, learning problems are also carried out based on joint deliberation. Students find their own problems or learning objects. In this case as many as 4 students accompanied by this delegating pattern. In table 3 above students in the order of numbers 1 through 4. To facilitate understanding, deliberately table 3 in the student number order according to the accompanying pattern. 


\section{Motivating pattern}

This motivating pattern is applied to students with characteristics of "high academic ability but low learning motivation". Motivating means that lecturers motivate students to solve the learning problems that lecturers give. Learning problems can be offered and found together between students and lecturers, but can be purely derived from lecturers. In this case as many as 4 students accompanied by this motivating pattern. In table 3 above students in the order of numbers 5 through 8 . To facilitate understanding, deliberately table 3 in the student number order according to the accompanying pattern.

In generating the motivation of student learning is done various ways that Masni (2015) said that in lesson maps ways to increase learning motivation into two, namely: developing learning materials and maximizing the way educators teach. Meanwhile, (Syaparuddin et al 2020), namely: providing a new stimulus, providing opportunities for students to channel their learning desires, using various media.

\section{Participating pattern}

This participating pattern is applied to students with characteristics of "low academic ability but high learning motivation". Participating means that lecturers involve students fully in the learning process. Students are invited together to find the object of learning problems. Students are accompanied intensely in the process of the finding the problems. Lecturers assist students in completing tasks in detail, even every step in completing the assignment, the student accompanied him. In this case as many as 4 students accompanied by this motivating pattern. In table 3 above students in the order of numbers 9 through 12. To facilitate understanding, deliberately table 3 in the student number order according to the accompanying pattern.

Concrete ways of engaging students in the learning process are: (1) C1-S1:High academic capability and motivation-delegeting (2) C2-S2 High academic capability and low motivation- motivating (3) C3-S3 low academic capability and high motivating-participating (4) low academic capability and motivating- intructing (Djohar and Istingsih, 2017)

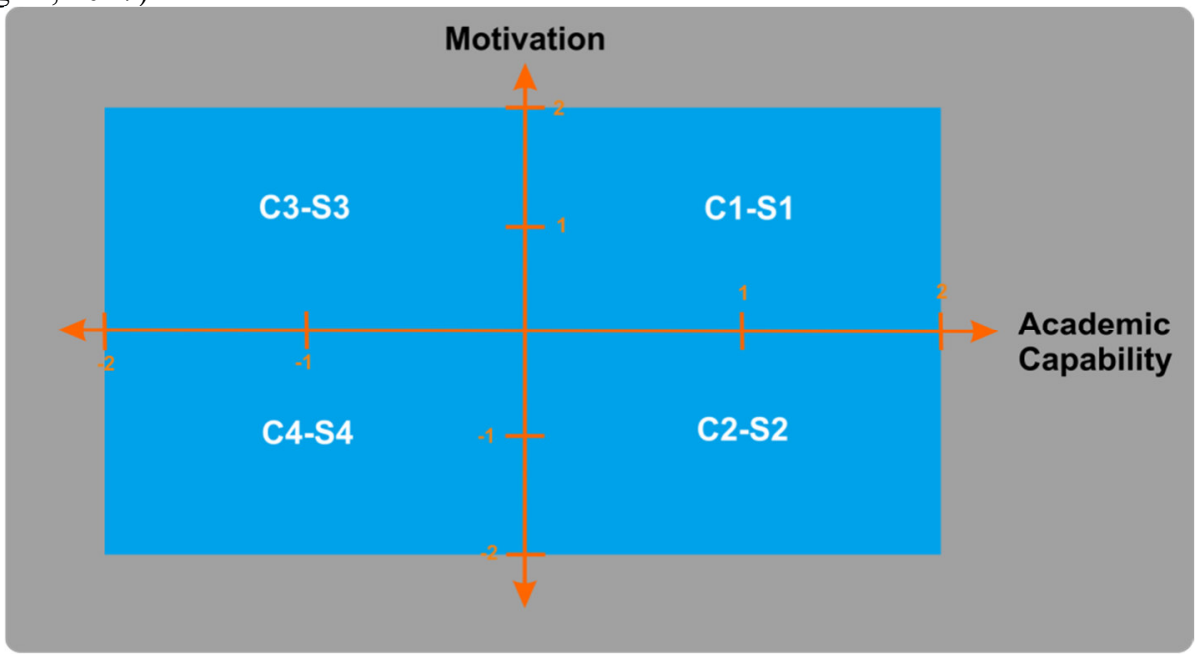

Figure 1. Model of leadership (adopted for Djohar and Istingsih, 2017)

\section{Instructing pattern}

This instructing pattern is applied to students with characteristics of "low academic ability and low learning motivation". Instructing means that lecturers provide learning objects to students and accompany students intensely in the sedation of the learning objects. This instructing pattern is a combination of motivating and participating. In this case as many as 4 students accompanied by this motivating pattern. In table 3 above students with the order of numbers 13 through 16. To facilitate understanding, deliberately table 3 in the student number order according to the accompanying pattern. In the implementation of mentoring to students who are in this category, lecturers control the motivation of student learning as well as control students in the completion of learning objects given to them. Thus more comprehensive capabilities are needed for lecturers.

Since this pattern is a combination of two mitavating and participating patterns, it is not repeated in this section how technical the implementation is, certainly the same as the one described in the section above. In applying the pattern of mentoring is required special requirements for lecturers. For lecturers who apply the delegating pattern that students want to solve the learning problems that lecturers give to them. Learning problems can be offered and found together between students and lecturers, but can be purely derived from lecturers. 
Tendency to change academic capability and motivation of student learning after accompanied by situational pattern

Changes in academic ability and motivation of student learning were measured by collecting data as much as 6 observations which followed data from the results of the anticipated observations. The collected data is listed in table 3 above. Next the data is processed and described to obtain the minumum, maximum, and average values in the table below.

\section{Tendency of academic capaability of students after accompanied by situational type}

Observations were made 6 times. The first observations were made before the assistance was carried out. Further observation after the assistance is made that each observation takes approximately 2-3 weeks. Based on the table below, the acdemic capability before being accompanied as 2.57 , next on the 2-5 accomponiment were 2 . $54 ; 2$. $51 ; 2.59 ; 2.63$; for observations to the 6 th or last average score was 2.62 .

\section{Motivational tendencies of learning students after accompanied by situational type}

Observations were made 6 times. The first observations were made before the accomponiment was carried out. Further observation after the accomponiment is made that each observation takes approximately 2-3 weeks. Based on the table below the learning motivation of the students before accomponiment as 2.61 , then on the $2-5$ accomponiment were $2.57 ; 2.41 ; 2.72 ; 2.51$; for observations to the 6 th or last average score of 2.62 .

The above scores are in one category, namely the moderate category. Thus it can be interpreted that this situational mentoring model has not been able to move the high category towards the motivation of student learning. When observed through percentage statistics then the position before accompanied is at the number $53.75 \%$ and the end of the observation is at $53.96 \%$.

Based on the from the graph below, on the linear line, it can be stated that the increase in student learning motivation tends to increase althought but his line of disingena did not increase drastically. When compared to the linearity line variable academic capaability of students tends to be lower

Furthermore, it can be pared down why the motivational position of learning before and after the accompanying is in the same category. It can be stated that students unaccompanied by lecturers have the ability to increase their own learning motivation. This is in accordance with the opinion (Muhammad, 2016) that students who are in the age of approximately 20-26 years have high intrinsic motivational abilities. He is able to motivate himself because students are personnel who have ideals and a future.

According to (Salam and Efendi, 2008) goals are variables that can trigger the growth of a motivation. Nevertheless, the presence of lecturers to accompany students is still required. The seizure of lecturers is a variable called extrinsic motivation. However, the amount of mentoring from lecturers still contributes to the improvement of student learning motivation.

To clarify the above description both the data description and the analysis of the results of the data below is displayed the line of changes in academic capability of black line, while the green line is a trend line graph

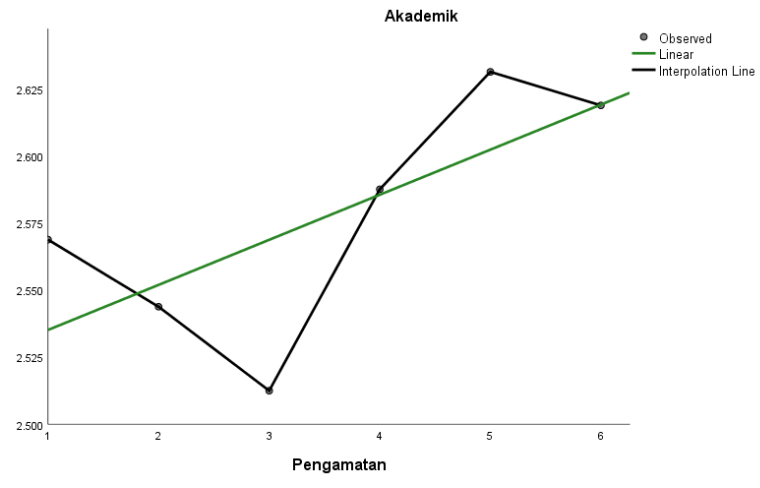

Graph 1. The Trend Of Academic Capability Change 
Descriptive Statistics

Table 4. Academic Capability

\begin{tabular}{lrrrrr}
\hline & N & \multicolumn{1}{c}{ Minimum } & \multicolumn{1}{c}{ Maximum } & Mean & Std. Deviation \\
\hline Aka1 & 16 & 1 & 4 & 2.57 & .737 \\
Aka2 & 16 & 1 & 3 & 2.54 & .653 \\
Aka3 & 16 & 1 & 3 & 2.51 & .726 \\
Aka4 & 16 & 1 & 4 & 2.59 & .748 \\
Aka5 & 16 & 1 & 4 & 2.63 & .864 \\
Aka6 & 16 & 2 & 4 & 2.62 & .783 \\
Akademik & 16 & 1.68 & 3.42 & 2.5771 & .65757 \\
Valid N (listwise) & 16 & & & & \\
\hline
\end{tabular}

Table 5. Trend Of Academic Capability Change (Percentage).

Descriptive Statistics (Percent)

\begin{tabular}{lrrrrr}
\hline & $\mathrm{N}$ & \multicolumn{1}{c}{ Minimum } & Maximum & Mean & Std. Deviation \\
\hline PAka1 & 16 & 6.67 & 90.00 & 52.2917 & 24.57698 \\
PAka2 & 16 & 6.67 & 76.67 & 51.4583 & 21.77218 \\
PAka3 & 16 & 6.67 & 80.00 & 50.4167 & 24.18677 \\
PAka4 & 16 & 3.33 & 93.33 & 52.9167 & 24.94067 \\
PAka5 & 16 & 6.67 & 93.33 & 54.3750 & 28.79606 \\
PAka6 & 16 & 16.67 & 93.33 & 53.9583 & 26.11141 \\
Akademik & 16 & 22.78 & 80.56 & 52.5694 & 21.91911 \\
Valid N (listwise) & 16 & & & & \\
\hline
\end{tabular}

The above scores are in one category, namely the moderate category. Thus it can be interpreted that this situational accompaniment model has not been able to move the high category towards the academic capaability of students. When observed through percentage statistics then the position before accompanied is at the number $52.29 \%$ and the end of the observation is at $52.57 \%$.

From the graph below linear lines can be stated that the improvement in the students' academic caability tends to increase, althougt but his line of disingena did not increase drastically. When compared to the linearity line variable motivation of students tends to be higher.

It can then be pared down as to why academic capability positions before and after being accompanied are in the same category. It can be stated that unaccompanied students by lecturers have the ability to improve their own academic abilities. This is in accordance with the opinion (Ernawati, 2011) that students in today's era of advanced technology are simply searching for material without having to be accompanied by lecturers. But that doesn't mean the presence of lecturers isn't necessary. Lecturers are still obliged to outline lectures and demonstrate the skills that students will achieve.

To clarify the above description both the data description and the analysis of the results of the data below is displayed the line of changes in learning motivation of black line, while the green line is a trend line (graph 2).

Motivasi

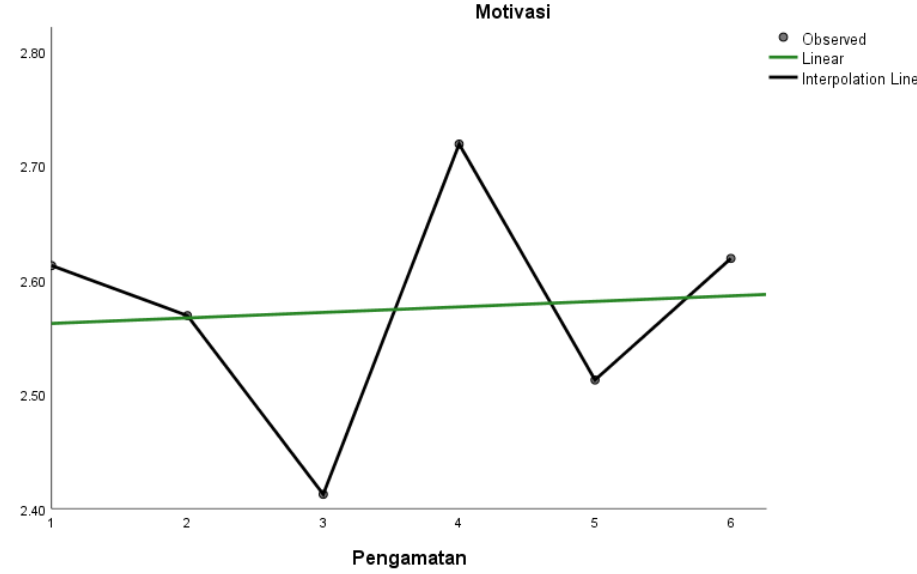

Graph 2. The Trned Of Motivation Change 
Table 6. Motivation

Descriptive Statistics

\begin{tabular}{lrrrrr}
\hline & N & \multicolumn{1}{c}{ Minimum } & \multicolumn{1}{c}{ Maximum } & Mean & Std. Deviation \\
\hline Mot1 & 16 & 1 & 4 & 2.61 & .644 \\
Mot2 & 16 & 1 & 3 & 2.57 & .612 \\
Mot3 & 16 & 1 & 3 & 2.41 & .591 \\
Mot4 & 16 & 2 & 4 & 2.72 & .581 \\
Mot5 & 16 & 1 & 4 & 2.51 & .769 \\
Mot6 & 16 & 1 & 4 & 2.62 & .713 \\
Motivasi & 16 & 1.90 & 3.27 & 2.5740 & .55280 \\
Valid N (listwise) & 16 & & & & \\
\hline
\end{tabular}

Tabel 7. The Trend Of Learning Motivation (Percentage)

Descriptive Statistics (Percent)

\begin{tabular}{lrrrrr}
\hline & $\mathrm{N}$ & \multicolumn{1}{c}{ Minimum } & \multicolumn{1}{c}{ Maximum } & Mean & Std. Deviation \\
\hline PMot1 & 16 & 13.33 & 83.33 & 53.7500 & 21.46056 \\
PMot2 & 16 & 13.33 & 80.00 & 52.2917 & 20.39313 \\
PMot3 & 16 & 6.67 & 73.33 & 47.0833 & 19.69678 \\
PMot4 & 16 & 26.67 & 93.33 & 57.2917 & 19.36850 \\
PMot5 & 16 & 6.67 & 86.67 & 50.4167 & 25.64357 \\
PMot6 & 16 & 13.33 & 93.33 & 53.9583 & 23.76486 \\
Motivasi & 16 & 30.00 & 75.56 & 52.4653 & 18.42678 \\
Valid N (listwise) & 16 & & & & \\
\hline
\end{tabular}

\section{Reference}

Aisyah, S., Takdir, S., 2017. Implementasi Gaya Kepemimpinan Situasional Kepala Sekolah Di Smp Negeri 1 Wamena Kabupaten Jayawijaya. Jurnal Kepemimpinan dan Pengurusan Sekolah 2, 119-132. https://doi.org/10.34125/kp.v2i2.116

$$
\text { David. } 2011 .
$$

Pendampingan

Petani,

Masih

Perlukah? https://ardhiandavid.wordpress.com/tag/pendampingan/

Blanchard., Hersey. 1977. Management of Organizational Behavior. Englewood Cliffs, New Jersey: Prentice Hill. Inc.

Blanchard., Hersey. 1997. Management of Organizational Behavior:Publishing Human Resources. Third Edition. New York: Prentice Hill. Inc.

Bophy, J. 1987. Synthesis of Research on Strategies for Motivating Student to Learn. Educational Leadership.

Creswell and Wisdom J. 2013. Research Design Qualitative, Quantitative, and Mixed Methods Approaches. third Edition. Terjemah, Achmad Fawaid, Desain Penelitian Pendekatan Kualitatif, Kuantitatif, dan Mixed. Yogyakarta: Pustaka Pelajar

Dahar, M. A. 2011. Relationship Between the School Resuorce Inputs and Academic Achievement of Student at Secondary Level In Pakistan. Thesis. Islamabad: Higher Education Commision Pakistan.

Departemen Pertanian. 2004. Ketahanan Pangan dan penyedia Lapangan Kerja: Jakarta

Direktorat Bantuan Sosial, 2007, Pedoman Pendamping Pada Rumah Perlindungan dan Trauma Center, Jakarta: Departemen Sosial

Djaali, 2009, Psikologi Pendidikan. Cetakan Ke 4. Jakarta: Bumi Aksara

Djohar, Istiningsih, 2017, Filsafat Pendidikan Ki Hajar Dewantara dalam Kehidupan Nyata, Yogyakarta: Suluh Media.

Ernawati E., "Perilaku Pencarian Informasi dan Kemampuan Mahasiswa Menulis Pendahuluan Penelitian: Studi Kasus Mata Kuliah Chinese Scientific Writing”, Humaniora Journal 2 (2): (2011): 1182-1192. Link. https://journal.binus.ac.id/index.php/Humaniora/article/viewFile/3169/2555

Fiere, Paulo. 2008. Pendidikan Kaum Tertindas, terj: tim redaksi. Jakarta: LP3ES.

Hamzah B. Uno, 2009. Teori Motivasi dan Pengukurannya Analisis di Bidang Pendidikan. Jakarta: PT Bumi Aksara

Istiningsih. 2008. Pendampingan Berbasis Among dalam Penyuluhan Pertanian (bagi Petani Padi Organik Di Sleman Yogyakarta). Yogyakarta: Universitas Negeri Yogyakarta

Jamasy Owin, 2001, Memahami Makna Pendamingan, Comunity Development dan Comunity Organizing. Link:https://comdevcentre.wordpress.com/2009/05/16/memahami-makna-pendampingan-coomunitydevelopment-dan-community-organizing/amp/

Krishnawati, N. dan Suryani, Y. 2010. Bahan Dasar untuk Pelayanan Konseling pada Satuan Pendidikan 
Menengah Jilid III. Jakarta: Grasindo, (Online),

Komsiyah L, 2012, Belajar dan Pebelajaran. Cetakan I. Yogyakarta: Penerbit Teras

Maryam Muhammad, “Pengaruh Motivasi Dalam Pembelajaran”, Lantanida Journal 4 (2) (2016): 87-97. Link. https://jurnal.ar-raniry.ac.id/index.php/lantanida/article/view/1881/1402

Masni. H., 2015. "Strategi Meningkatkan Motivasi Belajar Mahasiswa" Jurnal Dikdaya: Universitas Batanghari. Link: http://dikdaya.unbari.ac.id/index.php/dikdaya/article/view/64

McGrew, K. S. 2008. Beyond IQ: A Model of Academic Competence \& Motivation (MACM), (Online), (http://www.iapsych.com/acmcewok/Academicabilityconception.html), diakses 10 Maret 2013.

Miles, M.B \& Huberman A.M. 1984, Analisis Data Kualitatif. Terjemahan oleh Tjetjep Rohendi Rohidi. 1992. Jakarta : Penerbit Universitas Indonesia

Nursalam dan Efendi, 2008, Pendidikan dalam Keperawatan. Jakarta: Salemba Medika

Rivkin, S. G., Hanushek, E. A., dan Kain, J. F. 2005. Teacher, School, and Academic Achievement. Econometrica. Vol: 73(2): 417-458, (online), (http://fourpercentgrowthproject.com/downloads/theInstitute/educationRefo rm/AREL/AREL_Framework-Bibliography/Rivkin-Hanushek-and-Kain-Teachers-Schools-andAcademic-Achievement.pdf), diakses 20 Maret 2013.

Sugiyono. (2013). Metode Penelitian KOMBINASI (Mixed Methods). Bandung: Alfabeta

Sjukur B. Sulihin. 2012. "Pengaruh Blended Learning Terhadap Motivasi Belajar dan Hasil Belajar Siswa Tingkat SMK". Jurnal Pendidikan Vokasi. Link: https://journal.uny.ac.id/index.php/jpv/article/view/1043/844

Susilo R. 2011. Pendidikan Kesehatan dalam Keperawatan. Cetakan ke I. Yogyakarta: Muha Medika

Syaparuddin, Meldianus, Elihami. 2020. "Strategi Pembelajaran Aktif dalam Meningkatkan Motivasi Belajar PKn Peserta Didik". MAHAGURU: Jurnal Pendidikan Guru Sekolah Dasar. Link: https://ummaspul.ejournal.id/MGR/article/view/326/154

Thoha, Miftah, 1996. Perilaku Organisasi. Jakarta: Pt. Gramedia Pustaka Utama.

Yaumi Muhammad. 2018. "Perbaikan Kinerja Guru Madrasah Ibtidaiyah: Pelatihan, Perancangan, dan Pendampingan". Jurnal Teknologi Pendidikan. http://journal.unj.ac.id/unj/index.php/jtp/article/view/7844

Widiyanto, 2013, Statistik Terapan, Jakarta: PT. Elex Media Komputindo

Widyasari, 2017, "Kemandirian Belajar Mahasiswa PGSD Berdasarkan Ketersediaan Sumber Belajar”, Jurnal Sosial Humaniora. Link: https://ojs.unida.ac.id/JSH/article/view/906

Winkel, W. S. 2004. Psikologi Pendidikan dan Evaluasi Belajar. Jakarta: Pt. Gramedia Pustaka Utama 